\title{
THE FIGURES OF ODESA MAYORS IN THE SECOND HALF OF THE NINETEENTH AND THE EARLY TWENTIETH CENTURIES IN PRE- REVOLUTIONARY, SOVIET AND CURRENT RESEARCHES
}

\author{
Viktoriia Herasymenko \\ Postgraduate Student, Odesa I. I. Mechnikov National University, Ukraine \\ e-mail: samvika2086@gmail.com,orcid.org/0000-0003-2859-0105
}

\section{Summary}

The given article deals with the historical period: from the second part of the nineteenth to the beginning of the twentieth centuries when there was the "silver era" of Odesa city development. The article provides the initial analysis and classification of major historical publications that are basic for the creation of prosopographic portrait and related to the life and work of nine Odesa mayors such as: Semen Vorontsov, Mykola Novoselsky, Grigory Marazli, Valeryan Ligin, Petro Kryzhanovsky, Pavlo Zelenyi, Vasyl Protopopov, Mykola Moiseyev and Borys Pelikan who held the self-government office from the beginning of the City Regulations of 1863 until the turning points in the first half of the twentieth century - World War I. The material for the investigation was singled out from the works of mayors' contemporaries, Soviet researchers, modern Ukrainian and foreign historians. 45 published papers were analyzed. In the research, the following methods were used: the methods of synthesis and analysis and the method of critical thinking. Also the biographies and activities of Odesa city mayors were presented in the reviewed works. The findings have suggested that the history of city self-government and the role of city leaders in this process should be the subject of a special systematic and comprehensive study.

Keywords: Odesa city council, leader of self-government, prosopographic portrait, scientific works.

\section{DOI: https://doi.org/10.23856/4804}

\section{Introduction}

Nowadays a very young scientific discipline - prosopography caused a new look at the study of life and activity of historical figures, the need for their concretization and reflection in a set of life circumstances, family and non-family societies. The main tools of prosopography help to rediscover personalities in the context of their major periods of life.

The main focus in prosopographic studies concentrates on source base. However, information about many clarifying details about personal data, family ties, immediate environment, career growth, participation or role in historical events - can already be recorded in the works of scientists and contemporaries of Odesa mayors in the second half of the nineteenth century and early twentieth century.

The study of the history of hometowns is one of the most pressing issues of our time. Local historians are in constant search of discovering more new facts about the past of their native land. The history of city self-government and the role of individual historical figures in it still need thorough consideration.

The purpose of the article is to identify and analyze works of the past and current researches made by historians, politicians, cultural figures which are devoted to the activity of 
Odesa city mayors. These materials will help restore the picture of the history of urban self-government through the personalities of the leaders of Odesa for creation a prosopographic portrait. In accordance with the purpose, the use of the method of analysis and synthesis allowed analyzing the general state of scientific development of the topic in Ukrainian and foreign historiography, to group historiography by issues. The method of critical thinking was introduced in order to search, analyze, classify and select information by level of significance.

\section{The mayors' personalities and the research of them}

The City Regulations were introduced in Odesa city in 1863 (earlier than the national city reform of the 1870s) and gave more authority to the city leaders to innovate and implement progressive ideas. From the activation of the above-mentioned document until the beginning of the World War I, the position of the mayor of Odesa was held by the following personalities: Semen Vorontsov (1863-1867), Mykola Novoselsky (1867-1878), Grigory Marazli (1878-1895), Valeryan Ligin (1895-1897), Petro Kryzhanovsky (1897, 1905), Pavlo Zelenyi (1898-1905), Vasyl Protopopov (1906-1908), Mykola Moiseyev (1908-1913) and Borys Pelikan (1913-1917). For modern Odesa citizens such names as: S. Vorontsov, M. Novoselsky, G. Marazli are well-known, but they can tell not much about the activities of these people. The names of the other city mayors remain a mystery even for scientists.

It should be stressed that the study of the main figures of Odesa municipality has not been highlighted in detail too. There are scarce publications about the state of the city under the leadership of a certain mayor, biographical information about the mayors, or monographs devoted to the anniversaries of Odesa, which include the period after the enactment of the City Regulations in 1863 and before World War I.

For the more thorough analysis of the existing publications we have divided the whole historiographical process of the research into three periods: pre-revolutionary (XIX - early XX century), soviet (1921-1991) and present-day. The latter began with the proclamation of Ukrainian independence. Each of above-mentioned periods of the research of Odesa mayors' activity is marked by various socio-political reasons, the possibility of access to various sources and the implementation of scientific publications taking into account ideological principles.

\section{The pre-revolutionary historiography}

Contemporaries of Odesa mayors, such as stockbroker S. Bernstein and censor S. Plaksin, mostly described the general state and events in the city, mentioning only some sentences about the current mayors after 1863 City Reform (Bernstein, 1881; Plaksin, 1901). The similar trend can be traced in the special jubilee works - to the so-called 100th anniversary of Odesa foundation (1894) (Kirpichnikov, 1894; Odessa, 1894; Sinhronisticheskoe izobrazhenie, 1897: 5,7,9-10,13; Stoletiye Odessy, 1894).

A bright and fundamental example of the description of the mayor's activity is a brochure (extract from the "Novorossiysky Telegraph" newspaper of 1880) with an overview of the activities of such mayor as M. Novoselsky (Obzor deyatelnosti, 1880). The work less saturated with information is the reference from the biographical dictionary of Poltava province about V. Protopopov and the obituary about M. Novoselsky from the "Notes" of Odesa Society of History and Antiquities (Pavlovskij, 1914; Markevich, 1900).

Also an important issue is the availability of materials from the local press, namely, separate articles of the Duma, sketches written by journalists, newspaper editors and anonymous 
people. Quite revealing examples are biographical references with the portraits of Odesa mayors at election, essays on the celebration of holidays and professional anniversaries, feuilletons with assessments of activities, scandals, inter-election disputes, photos from illustrated newspaper supplements and obituaries, memoirs of the above-mentioned personalities.

Moreover, it should be noted that in the majority of the pre-revolutionary works, the assessments of mayors were positive; much emphasis was placed on the activities of G. Marazli and M. Novoselsky. The newspapers could have had more conflicting views, especially if the city government's decision did not meet to the demands of the local community.

\section{The Soviet period of research}

During the Soviet period, the study of the people of noble origin was unacceptable, and the events and phenomena of the post-reform era were deliberately silenced. In 1928, the anniversary collection on the existence of the newspaper "Odesa Herald" provided a brief review of the activities of one of the mayors - P. Zelenyi as the editor of the "Odesa Herald" newspaper for 1878-1884 (Berman, 1928).

Emphasizing on the working class of the population, a jubilee essay devoted to the 150th anniversary of Odesa as a hero city, mentioned one of the mayors. G. Marazli was mentioned as one of the constant leaders, "fathers" of the city, and in general the author of the section gave a positive assessment to the heads of self-government of Odesa in 1860-1890 (Dobrolyubskij, 1947: 85).

In 1960 a generalized popular science essay on the history of Odesa region and Odesa city appeared. In this book the period of active development of industry in the second half of the nineteenth century was mentioned. In particular, V. Zagoruyko specially mentioned several personalities, such as: M. Novoselsky, G. Marazli and P. Zelenyi who were Odesa mayors. M. Novoselsky was praised both for his economic views and initiatives, and for his important work to improve the city's infrastructure and communications. His successor, G. Marazli, appeared with a sharply opposite character, due to belonging to the largest business families of the time, who "made their millions on the wheat trade" and "for greater popularity - returned the crumbs of the acquired wealth to the public with great noise". The last mayor of the list, P. Zelenyi was mentioned as the editor of the "Odesa Herald" newspaper and the mayor. The author described P. Zelenyi neutrally, as a territorial liberal with progressive views, who maintained broad ties with the Ukrainian intelligentsia, foreign cultural figures and publishing houses (Zagorujko, 1960: 38-41).

During the Soviet period, the American researcher P. Herlihy came to Odesa and worked with the archival documents. After her visit the book "Odessa. A History, 1794 - 1914" was published in Harvard University (Herlihy, 1987).

In the text of the book the names of several mayors - S. Vorontsov, M. Novoselsky, G. Marazli and P. Zelenyi were mentioned. There were some details about their life and the period of activity as the heads of the city with interspersed memories of the contemporaries about their behavior and character.

\section{Contemporary Ukrainian and foreign historiography}

The transformation of this problem into an object of study took place only after Ukraine gained independence. General essays on the history of Odesa, written by present-day researchers, have references to the mayors of Odesa, their administrative, public and charitable activities (Stanko, 2002; Malahov, 2004; Grebcova, 2009; Libin, 2009: 229-232, 276-278; Demin, 2011). 
The publication of the monograph aimed at describing the activity of one of Odesa mayors, who devoted almost a quarter of his life to the service of Odesa - G. Marazli, became a positive shift to the profound investigation of the topic under analysis. Since 1990 s, the publications written by different researchers, local historians and employees of educational and cultural institutions on the life and various spheres of G. Marazli's activities have appeared regularly (Terenteva, 1994; G. G. Marazli, 1995; Kulyk, 1997; Izuvita, 1999; Chopp, 2000; Doncova, 2001; Hryhorii Marazli, 2006; Terentieva, 2006; Reshetov, 2007; Reshetov, 2012). Grigory Marazli is the most outspoken person among the cohort of mayors of the post-reform era.

Later M. Novoselsky, P. Zelenyi, and B. Pelikan - the mayors, who also received attention from modern scholars studying regional history, became the popular figures too (Krasyuk, 1993; Zlenko, 1994; Zlenko, 1997; Fajtelberg-Blank, 2008; Goncharuk, 2012). In particular, the figures of M. Novoselsky and B. Pelican in historians' investigations were highlighted by the same authors, namely, S. Reshetov and L. Izhik who wrote about G. Marazli (Reshetov, 2013; Izhik, 2014).

S. Vorontsov and V. Ligin were mentioned in single publications devoted to some episodes of Odesa life - activities in the Society of Fine Arts and the Imperial Novorossiya University (Savelieva, 2005; Abramov, 2009). The figures of P. Kryzhanovsky, V. Protopopov and M. Moiseyev have not been the subjects of definite investigations, articles, references yet, except for the works of the author (Palamarchuk 2017; Herasymenko, 2018; Herasymenko, 2021).

Foreign historiography also made contribution into the investigation of the activity of Odesa mayors. P. Herlihy continued her work on the study of historical events and figures of Odesa (Herlihy, 2018). The pages of Jewish history of Ukraine presented by O. Solzhenitsyn also described Odesa city, in particular the tragic events of 1905, where mayors played their significant role (Solzhenicyn, 2001).

The attention of Polish and German researchers was paid to V. Ligin, his family, and overseas activities of the government (Górak, 2016; Rolf, 2020). The modern reprint of the Court Calendar of 1915 finally shed light on the activity of one of the less-known mayors, M. Moiseyev (Krylov-Tolstikovich, 2015: 437).

\section{Conclusions}

The foregoing in this article allows us to conclude the following. In the first, pre-revolutionary, period, the general picture of the development of Odesa was covered in essays and works dedicated to the 100th anniversary. The names of the city mayors were mentioned scarcely in the sections of the above-mentioned works. Brief biographical information could be found only in obituaries. Their positions and public activities could be found on the pages of multi-volume reference books.

During the Soviet period, under the pressure of the so-called "class approach", political situation, communist ideology and lack of information, scientists failed to conduct a thorough study of Odesa city governmental leaders.

After gaining the state independence the significant changes took place in Ukraine. One of them was connected with history direction. The various researches (articles or monographs) on the history of the city began to be published. These papers included the descriptions of the mayors' biographies or highlighting some famous city personalities or covering the direction of government officials. The most studied public figure is G. Marazli, followed by M. Novoselsky, P. Zelenyi, B. Pelican. There is still a very limited amount of information about 
S. Vorontsov, V. Ligin, P. Kryzhanovsky, V. Protopopov and M. Moiseyev. Foreign researchers also write about the personalities of Odesa mayors, but only in connection with their family ties or foreign activities.

Thus, despite a great number of publications, the history of urban self-government and the role of city leaders have not yet been the subject of special systematic and comprehensive research. Due to prosopography and its tools, a significant shift in terms of studying the group of historical personalities of the city government of Odesa can take place.

\section{References}

Abramov, V. (2009). Pervaya vystavka Odesskogo obshestva izyashnyh iskusstv v 1865 godu [The first exhibition of the Odessa Society of Fine Arts in 1865]. Deribasovskaya-Rishelevskaya: Odesskij almanah, 37. Odessa: PLASKE. [In Russian].

Berman Ya., Z. (1928). Do stolitnikh rokovyn zasnuvannia hazety "Odesskyi vestnyk" [To the centenary of the founding of the "Odessa Herald" newspaper]. Kyiv. [in Ukrainian].

Bernshtejn, S. (1881). Odessa: istoricheskij i torgovo-ekonomicheskij ocherk Odessy v svyazi s Novorossijskim kraem [Odessa: historical, trade and economic essay of Odessa in connection with the Novorossiya Governorate]. Odessa: Tipografiya of L. Nitche. [In Russian].

Chopp, I. (2000). Premiya imeni Marazli [The Marazli Prize]. Deribasovskaya-Reshilevskaya. Odesskij almanah, 3. Odessa: PLASKE. [in Russian].

Demin, O. (2011). Odesskaya gorodskaya duma v epohu reformirovaniya Odesskogo gorodskogo samoupravleniya (60-80e gg. XIX v.) [Odessa City Duma in the era of reforming Odessa city government (60-80s of the XIXth century)]. Visnik Chernigivskogo nacionalno pedagogichnogo universitetu, 87. Chernigiv: Tipografiya Chernigivskij nacionalnij pedagogichnij universitet imeni T. G. Shevchenka. [In Russian].

Dobrolyubskij K. P. (Eds.). (1947). Odessa: ocherk istorii goroda-geroya $k$ 150-letiyu so dnya osnovaniya [Odessa: an essay of the history of the hero city to the 150th anniversary of its foundation]. Odess : Odesskoe obl. izd-vo. [in Russian].

Doncova, T. (2001). Moldovanka. Zapisi kraeveda [Moldovanka. The local history notes]. Odessa, Chernomore. [In Russian].

Fajtelberg-Blank, V. R., Savchenko, V. A. (2008). Odessa v epohu vojn i revolyucij, 1914-1920 [The Odessa in the era of wars and revolutions, 1914-1920]. Odessa: Optimum. [in Russian]. G. G. Marazli: mecenat i kollekcioner: Sb. Stattej [G. G. Marazli: philanthropist and collector: Collection of articles]. (1995). Odessa. [In Russian].

Goncharuk, T. G. (2012). Kak v nashi dni voshel vodoprovod [How the plumbing entered the present days]. Gazetnimi stezhkami. Odesa: Astroprint. [In Russian].

Górak, A., \& Latawiec, K. (2016). Russian Governors in the Kingdom of Poland (1867-1918). (J. Krajka, Trans). Lublin: ELPIL.

Grebcova, I. S. (2009). Novorossijskij universitet v razvitii blagotvoritelnosti v Odesse (vtoraya polovina XIX - nachalo XX st.): monografiya [The Imperial Novorossiya University in the development of charity in Odessa (second half of the XIX-early XX centuries): monograph]. Odessa: Astroprint. [In Russian].

Herasymenko, V. (2018). Miskyi holova Odesy 1905-1908 rr. Vasyl Yakovych Protopopov: korotkyi istorychnyi portret [The mayor of Odessa in 1905-1908 Vasily Yakovlevich Protopopov: a short historical portrait]. Pivdennyi zakhid. Odesyka. Istoryko-kraieznavchyi naukovyi almanakh, 25. Odesa: Drukarskyi dim. [in Ukrainian]. 
Herasymenko, V. (2021). Vidstavka miskoho holovy P. A. Kryzhanovskoho-hariacha novyna "Odesskykh novostei" hrudnia 1897 r. [The resignation of the mayor P. A. Kryzhanovsky - the hot news of "Odessa News" newspaper in December 1897.]. Pivdennyi zakhid. Odesyka. Istoryko-kraieznavchyi naukovyi almanakh, 30. Odesa: Drukarskyi dim. [in Ukrainian].

Herlihy, P. (2018). Odessa Recollected: The Port and the People. Brighton, MA: Academic Studies Press.

Herlihy, P. (1987). Odessa: A History, 1794-1914. Cambridge, MA: Harvard University Press. Hryhorii Marazli: Do 175-richchia vid dnia narodzhennia [Grigory Marazli: Until the 175 years after the birthday]. (2006). Odesa. [in Ukrainian].

Izhik, L. V. (2014). Knizhnye znaki odesskih bibliofilov: monograficheskoe issledovanie [The book signs of Odessa bibliophiles: the monographic research]. Odessa: Odesskaya nac. nauch. b-ka im. Gorkogo. [in Russian].

Izuvita, G. A. (1999). G. G. Marazli i Odesskij arheologicheskij muzej [G. G. Marazli and the Odessa Archaeological Museum]. Kratkie soobsheniya Odesskogo arheologicheskogo obshestva. Odessa. [In Russian].

Kirpichnikov, A. I. (1894). Proshloe i nastoyashee Odessy: izdanie Odesskoj Gorodskoj Auditorii Narodnyh chtenij ko dnyu stoletnyago yubileya g. Odessy (1794-1894) [The past and the present of Odessa: the publication of the Odessa City Auditorium of People's Readings on the day of the centenary of Odessa (1794-1894)]. Odessa: Tipografiya of L. Kirhnera. [in Russian]. Krasyuk, A. I. (1993). Istoriya Odesskogo vodoprovoda [History of the Odessa water supply system]. Odessa: Odessavodokanal. [in Russian].

Krylov-Tolstikovich, A. (2015). Pridvornyj kalendar na 1915 god. Kommentarii [The court calendar of 1915 year. Comments.]. Moscow. Retrieved from https://cutt.ly/jETOwka [in Russian]. Kulyk, Y. H. (1997). H. H. Marazly y Odesskoe prosveshchenye [Marazli and education sphere in Odessa]. Istorychnyi dosvid i suchasnist. Materialy konferentsii, 3. Odesa. [in Russian].

Libin, A. (Eds.) (2009). 100 velikih odessitov [100 great Odessa citizens]. Odessa: Optimum. [in Russian].

Malahov, V. P., Stepanenko, B. A. (2004). Odessa, 1900-1920 / Lyudi... Sobytiya... Fakty... / [Odessa, 1900-1920 / People ... Events ... Facts ... /]. Odessa: Optimum. [in Russian].

Markevich, A. I. (1900). Novoselskij N. A. Nekrolog [Novoselsky N. A. Obituary]. ZOOID, 22. Odessa. [in Russian].

Obzor deyatelnosti byvshego odesskogo gorodskogo golovy N. A. Novoselskogo [The review of the activities of the Odessa ex mayor N. A. Novoselsky]. (1880). Iz Novorossijskogo Telegrafa, 1545. Odessa. [in Russian].

Odessa. 1794-1894 [Odessa. 1794-1894]. (1894). Odessa: Tipografiya of A. Shulce. [in Russian]. Palamarchuk, V. (2017). Miskyi holova Petro Adamovych Kryzhanovskyi - "kazkovyi prynts, shcho maie rozbudyty spliachu krasuniu Odesu” [The mayor Petro Adamovych Kryzhanovsky"a fabulous prince who should wake up the sleeping beautiful Odesa”]. Pivdennyi zakhid. Odesyka. Istoryko-kraieznavchyi naukovyi almanakh, 23. Odesa: Drukarskyi dim. [in Ukrainian]. Pavlovskij, I. F. (1914). Poltavcy: ierarhi, gosudarstvennye i obshestvennye deyateli i blagotvoriteli: opyt kratkogo biograficheskogo slovarya Poltavskoj gubernii s poloviny XVIII v. [Poltava citizens: the hierarchs, the statesmen and the public figures and the benefactors. The experience of a short biographical dictionary of the Poltava province from the middle of the 18th century.]. Poltava, Tovarishestvo Pechatnogo Dela. Retrieved from https://cutt.ly/9ETO2KD [in Russian].

Plaksin, S. (1901). Kommerchesko-promyshlennaya Odessa i yeye predstaviteli $v$ kontse devyatnadtsatogo stoletiya $i$ istoriya razvitiya torgovykh firm s prilozheniyem adresnykh svedeniy 
[The commercial and industrial Odessa and its representatives at the end of the nineteenth century and the history of the development of trading companies with the attachment of address information]. Odessa: Slavic Tipografiya N. Chrysogelos [in Russian].

Reshetov, S., Izhik, L. (2012). Grigoriy Marazli. Chest' pache pochesti [Grigory Marazli. Honor is more than honor]. Odessa: TES. [in Russian].

Reshetov, S., Izhik, L. (2007). Gorodskoj golova Odessy G. G. Marazli (1831-1907) i ego rodstvennoe okruzhenie [The mayor of Odessa G. G. Marazli (1831-1907) and his family entourage]. Deribasovskaya-Rishelevskaya: Odesskij almanah, 31. Odessa: PLASKE. Retrieved from http://odessitclub.org/publications/almanac/alm_31/alm_31_6-31.pdf [in Russian]

Reshetov, S., Izhik, L. (2013). O dome gorodskogo golovy Odessy N. A. Novoselskogo [About the house of the Odessa mayor N. Novoselsky]. Deribasovskaya-Rishelevskaya: Odesskij almanah, 54. Odessa: PLASKE. [in Russian].

Rolf, M. (2020). Pol'skiye zemli pod vlast'yu Peterburga: ot Venskogo kongressa do Pervoy mirovoy [Polish lands under the rule of St. Petersburg: from the Congress of Vienna to the First World War] (C. Levinson, Trans). Moscow: New Literary Review. Retrieved from https://cutt. ly/sjOuWpl [in Russian].

Savelieva, E. V. (2005). Lihin V. M. [Ligin V. M.]. Profesory Odes'koho (Novorosiys'koho) universytetu (Vol. 3). Odesa: Astroprint. [in Ukrainian]

Sinhronisticheskoe izobrazhenie glavnejshih sobytij iz zhizni goroda Odessy, sostavlennoe svyashennikom Ioannom Dariomedovym v pamyat stoletnej godovshiny so dnya v Boze pochivshej osnovatelnicy Odessy Imperatricy Ekateriny II [The synchronic depiction of the main events in the Odessa city life, compiled by priest John Dariomedov in memory of the centenary of the death of Odessa founder Empress Catherine II]. (1897). Odessa: Tipografiya Novorossijskogo telegrafa. [in Russian].

Solzhenicyn, A. I. (2001). Dvesti let vmeste [Two hundred years together]. Vol. 1. Moscow: Russkij put. [in Russian]

Stanko, V. N. (Eds.). (2002). Istoriya Odesy [History of Odesa]. Odesa: Druk. [in Ukrainian]. Stoletiye Odessy. S portretami administrativnykh i obshchestvennykh deyateley $i$ s vidami Odessy [Centenary of Odessa. With portraits of administrative and public figures and views of Odessa]. (1894). Odessa: Tipografiya L. Nitsche. [in Russian].

Terenteva, N. A. (1994). Semia Marazly v Odesse [The Marazli family in Odessa]. Odesi-200. Tezy dopovidei. Odesa. [in Ukrainian].

Terentieva, N. O. (2006). Blahodiina diialnist rodyny Marazli z budivnytstva ta utrymannia ustanov Odesy kulturno-osvitnoho napriamu [The charitable activity of the Marazli family on Odessa construction and maintenance of institutions from the cultural and educational spheres]. Problemy istorii Ukrainy XIX-pochatku XX st. Kyiv: Instytut istorii Ukrainy NAN Ukrainy. [in Ukrainian].

Zagorujko, V. (1960). Po stranicam istorii Odessy i Odesshiny [Through the pages of the history of Odessa and Odessa region]. (Vol 2). Odessa: Odes. obl. izd-vo. [in Russian].

Zlenko, H. (1997). Pavlo Zelenyi-odeskyi miskyi holova i literator [Pavlo Zelenyi is the mayor of Odessa and a writer]. Kyivska starovyna, 6. Kyiv, ArtEk. [in Ukrainian].

Zlenko, H. D. (1994). Stanovlennia ukraïnskoï presy v Odesi (kinets XIX-pochatok XX st.) [The formation of the Ukrainian press in Odesa (the late 19th - the early 20th centuries.)]. Odesi-200. Tezy dopovidei. Odesa. [in Ukrainian]. 